\title{
Effect of P Rates Combined with PDB on Nutrients Uptake by Wheat Grown Under Organic Farming of Sandy Soil Using ${ }^{15} \mathrm{~N}$ Tracer Technique
}

\author{
Z. A. Zaki ${ }^{1}$, F. M. Habib ${ }^{2}$, Y.G. M. Galal*1, and A. H. Abd El- Hameed ${ }^{2}$ \\ (1) Soil and Water Research Department, Nuclear Research Center, Atomic Energy Authority Egypt \\ (2) Soils and Water Department, Faculty of Agriculture, Benha University, Egypt
}

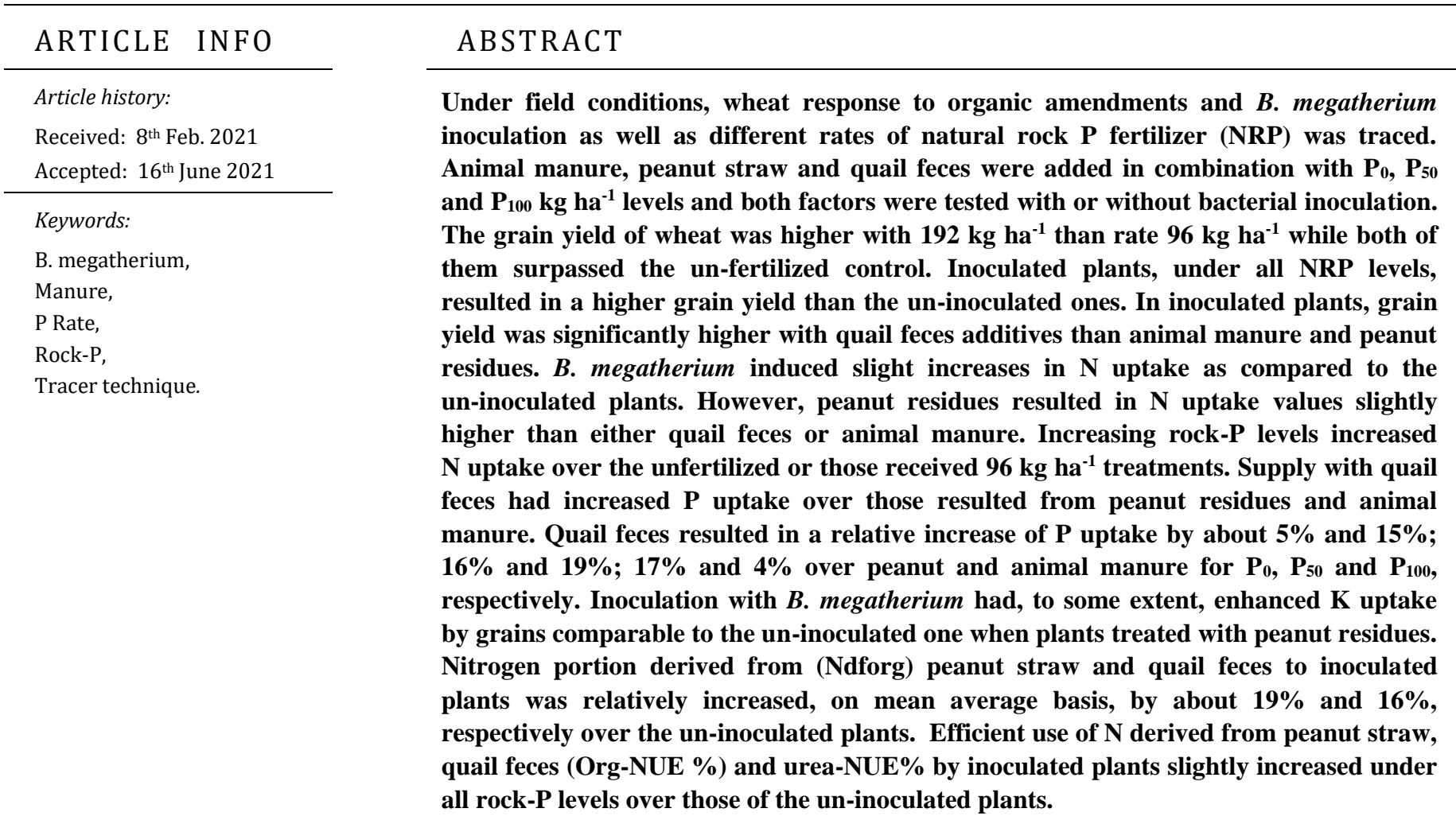

\section{INTRODUCTION}

Wheat (Triticum aestivum) as one of the important cereal crops was exposed to integrated fertilization strategy including the combined application of organic manure, synthetic fertilizers and microbial inoculants. An entire range of microorganisms contains living organisms that could promote growth through enhancement of nutrients supply to the host plant and favoring soil fertility $[1,2]$.

Microbial inoculation was considered for improving plant growth, quality and it was responsible for the optimized yield of wheat [3, 4]. This strategy was considered as renewable source of plant nutrients and implemented in increasing the availability of immobilized or sparingly soluble nutrients [5]. Also, such microbes may change or modify soil reaction, increase the total $\mathrm{N}$ and available $\mathrm{P}$ and $\mathrm{K}$.

The essentiality of phosphorus to plant was recognized [6], but its availability to plants is limited, which leads to plant growth restrictions [7]. Rational application of manufactured $\mathrm{P}$ and its efficient use could protect the environment [8], and optimize crop $\mathrm{P}$ utilization [9]. In arid regions, soil $\mathrm{P}$ availability was negatively affected by low soil organic matter content and high temperature [10]. To overcome this problem, bio-fertilization strategies existed to improve soil $\mathrm{P}$ availability [11], and it is considered eco-friendly and cost- effective management practice $[12,13]$. In this 
regard, either solubilization or mineralization of mineral and organic-P could be achieved through the inoculation with P-solubilizing bacteria (PSB) $[14,15]$. Soil supplied with organic amendments and bio-fertilizer either individually or in combination reflected high seed yields of wheat attributable to enhancement of $\mathrm{N}, \mathrm{P}$, and $\mathrm{K}$ availability and improvement of organic matter content[16].

Accordingly, this work aimed to evaluate different organic additives and inoculation with $B$. megatherium as PSB role in improving wheat growth and NPK uptake and availability of $\mathrm{P}$ from natural rock-P added at different rates. Application of ${ }^{15} \mathrm{~N}$ technique implemented in distinguishing the portions of $\mathrm{N}$ derived by the plant from different sources, i.e., $\mathrm{N}$ derived from organic sources, from urea and those remained in the soil after harvest and $\mathrm{N}$ use efficiency and $\mathrm{N}$ fertilizer balance.

\section{Materials and Methods}

Wheat grains (Triticum aestivum L. Giza 171), provided by the Cereal Crop Research Department, Institute of Field Crops Research, Agriculture Research Center, Giza, Egypt, were sown at the winter season 2018/2019 in 2 December 2018 in sandy soil (Table 1). Organic additives, i.e., animal manure, peanut straw, and quail feces, were obtained from relevant farms at the Nuclear Research Center, were incorporated into the soil under seed bed one month before sowing to offer proper decay of organic constituents. Chemical constituents of these resources are listed in Table (2). Potassium fertilizer was applied before sowing at $120 \mathrm{~kg} \mathrm{ha}^{-1}$ in the form of potassium sulfate (48\%). Organic additives were applied based on its nitrogen content. In this respect, animal manure with $1.6 \% \mathrm{~N}$ was applied at the rate of $15000 \mathrm{~kg} \mathrm{ha}^{-1}$ equal to $240 \mathrm{~kg} \mathrm{~N} \mathrm{ha}{ }^{-1}$. Peanut straw $(2.3 \% \mathrm{~N})$ was applied at the rate of $10434 \mathrm{~kg} \mathrm{ha}^{-1}$ equal to $240 \mathrm{~kg} \mathrm{~N} \mathrm{ha}{ }^{-1}$, while quail feces $(4.2 \% \mathrm{~N})$ were applied at $5714 \mathrm{~kg} \mathrm{ha}^{-1}$ equal to $240 \mathrm{~kg} \mathrm{~N} \mathrm{ha}^{-1}$. Rock-P $(29 \%$ P) was used as a phosphorus source and applied at three different rates i.e., $0,50 \%$, and $100 \%$ from the recommended rate $\left(192 \mathrm{~kg} \mathrm{ha}^{-1}\right)$. All organic treatments and $\mathrm{P}$ levels were applied in the presence or absence of Bacillus megatherium (inoculation) provided by Agriculture Microbiology Department, Institute of Soil, Water and Environment, Agriculture Research Center, Giza, Egypt. The treatments could be summarized as follows:

1- Three different organic additives namely, animal manure, peanut straw and quail feces.
2- Three different rock-P levels, i.e. 0, 50 and 100\% from the recommended rate.

3- With or without inoculation (phosphate dissolving bacteria).

4- The experiment consists of 3 organic treatments $x 3$ $\mathrm{P}$ levels $\mathrm{x} 2$ inoculation $\mathrm{x} 3$ replicates equal to 54 plots.

Isotope dilution concept $\left({ }^{15} \mathrm{~N} /{ }^{14} \mathrm{~N}\right.$ ratio) was followed to trace nitrogen released from the organic forms and utilized by wheat crop. ${ }^{15} \mathrm{~N}$ labeled urea with $2 \%$ atom excess was applied at a half dose of the recommended $\mathrm{N}$ rate and combined with half-dose applied in the organic form to comprise $100 \%$ of recommended $\mathrm{N}$ rate. The isotopic technique was applied in micro-plot with $1 \mathrm{~m}^{2}$ area. Only data to distinguish between the different $\mathrm{N}$ sources gained by plants and their efficiency (NUE \%) was estimated from this micro-plot. The experimental design was a split-plot design in a randomized complete blocks arrangement with three replications. The treatments were arranged in a split-split block design where bacterial inoculation lies in the main blocks and rock-P levels distributed in sub-plot and organic additives in the sub-sub-plots.

The experiment was harvested at the beginning of May 2019 (about 150 days), plant and soil samples were collected, air-dried and transferred to the lab for chemical analyses. Plant samples were separated into shoots, roots and grains. All organs were oven-dried at $70{ }^{\circ} \mathrm{C}$ until constant weight. The dry weight of each organ was recorded in addition to dry seed yield.

\section{Methodology}

- Soil and organic sources analyses were carried out according to Carter and Gregorich [17].

- Plant analyses were carried out as described by Estefan et al., [18].

- ${ }^{14} \mathrm{~N} /{ }^{15} \mathrm{~N}$ ratio analysis was carried out using the NOI-6 PC emission spectrometer. Details of isotope dilution technique are described by IAEA-TECDOC no. 14 [19]. Standard equations were used for the calculation of nitrogen derived from different $\mathrm{N}$ sources in addition to nitrogen use efficiency (\%NUE).

The obtained data were statistically analyzed using SAS, software program, [20]. The Least Significant Deference (L.S.D) at the 0.05 level was detected. 
TABLE (1): Some physical and chemical characteristics of the experimental soil

\begin{tabular}{|c|c|c|c|c|c|c|c|c|c|c|c|}
\hline \multicolumn{4}{|c|}{ Particle size distribution (\%) } & \multirow{2}{*}{\multicolumn{2}{|c|}{$\begin{array}{c}\text { Texture class } \\
\text { Sand }\end{array}$}} & \multicolumn{2}{|c|}{$\begin{array}{l}\text { Bulk density } \\
\mathrm{g} \mathrm{cm}^{3}\end{array}$} & \multicolumn{2}{|c|}{$\begin{array}{c}\text { F.C. } \\
\%\end{array}$} & \multicolumn{2}{|c|}{$\begin{array}{l}\text { PWP } \\
\%\end{array}$} \\
\hline Sand & \multicolumn{2}{|c|}{ Silt } & Clay & & & \multicolumn{2}{|c|}{1.37} & \multicolumn{2}{|c|}{9.2} & \multicolumn{2}{|c|}{2.1} \\
\hline 87.6 & \multicolumn{2}{|c|}{4.5} & 7.9 & \multirow{2}{*}{\multicolumn{4}{|c|}{$\begin{array}{l}\text { Soluble cations } \\
\text { (meq } 100 \mathrm{~g}^{-1} \text { soil) }\end{array}$}} & \multirow{2}{*}{\multicolumn{4}{|c|}{$\begin{array}{l}\text { Soluble anions } \\
\text { (meq } 100 \mathrm{~g}^{-1} \text { soil) }\end{array}$}} \\
\hline$\underset{1: 2.5}{\mathrm{pH}}$ & $\underset{\%}{\mathrm{CaCO}_{3}}$ & O.M \% & $\begin{array}{c}\text { EC (dS } \\
\left.\mathrm{m}^{-1}\right) \text { at } 25 \\
{ }_{0} \mathrm{C}\end{array}$ & & & & & & & & \\
\hline \multirow{2}{*}{7.4} & \multirow{2}{*}{0.0} & \multirow{2}{*}{0.35} & \multirow{2}{*}{1.67} & $\mathbf{C a}^{++}$ & $\mathbf{M g}^{++}$ & $\mathrm{Na}^{+}$ & $\mathbf{K}^{+}$ & $\mathrm{CO}_{3}^{--}$ & $\mathrm{HCO}_{3}^{-}$ & $\mathrm{Cl}^{-}$ & $\mathrm{SO}_{4}^{--}$ \\
\hline & & & & 3.8 & 7.5 & 1.8 & 3.6 & - & 4.4 & 5.9 & 6.4 \\
\hline
\end{tabular}

TABLE (2): Some chemical characteristics of organic sources

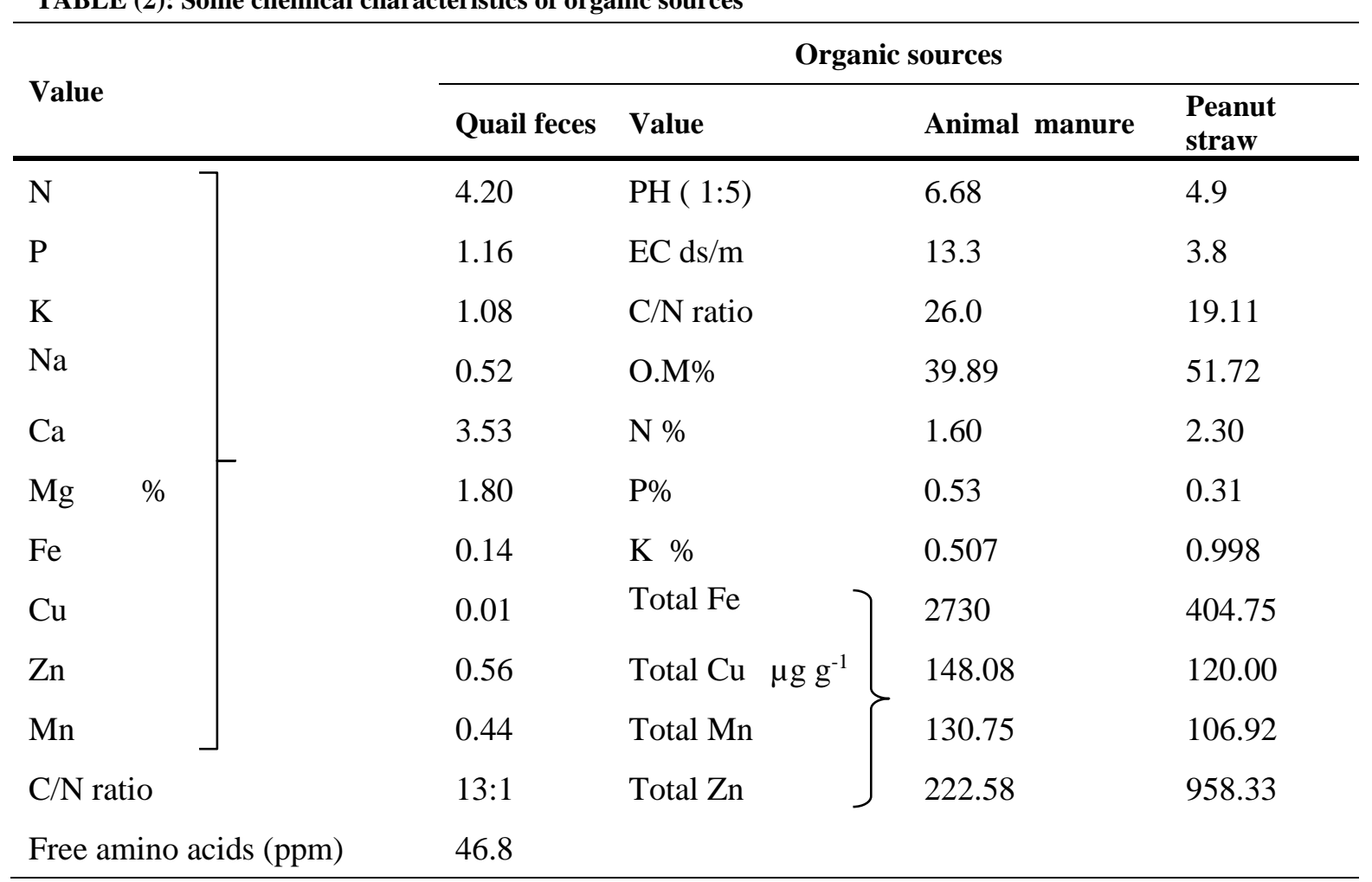

\section{RESULTS AND DISCUSSION}

\section{Grain yield}

Soil supplied with different rates of natural rock phosphate (NRP) and treated with different organic sources showed an increase in grain yield with increasing NRP rates (Fig. 1). This was true with inoculated and un-inoculated plants. Comparison between organic additives reflected a significant difference in grain yield of the un-inoculated wheat plants. This finding was true in case of inoculated and the un-inoculated plants. Dealing with the effect of NRP, there was a significant difference in the grain yield where it slightly increased with increasing NRP levels. The highest grain yield was detected with $192 \mathrm{~kg} \mathrm{P} \mathrm{ha}^{-1}$ followed by $90 \mathrm{~kg} \mathrm{P} \mathrm{ha}{ }^{-1}$ and both of them were significantly higher than the un-fertilized control. Inoculated plants, under all NRP levels, resulted in a higher grain yield than the un-inoculated ones. In inoculated plants, the grain yield was significantly higher with quail feces additives than animal manure and peanut residues, respectively.

As for the effect of organic manures on the grain yield, Abd El-Hamid, et al., [16] indicated that a highly significant relative increase in wheat seed yield was recorded by about $24.87 \%, 39.08 \%$ and $42.93 \%$ over the untreated soil for compost added at the rate of 2.5, 5 and 7.5 ton $\mathrm{fed}^{-1}$, respectively under newly reclaimed sand soil. Under field conditions, the content of available $\mathrm{P}$ and $\mathrm{K}$ in the soil has increased significantly due to inoculation with combined microbial fertilizer containing A. brasilense, B. subtilis, B. licheniformis, and $B$. mucilaginosus, which helps in dissolving the insoluble $\mathrm{P}$ and $\mathrm{K}$ in the soil [21]. 


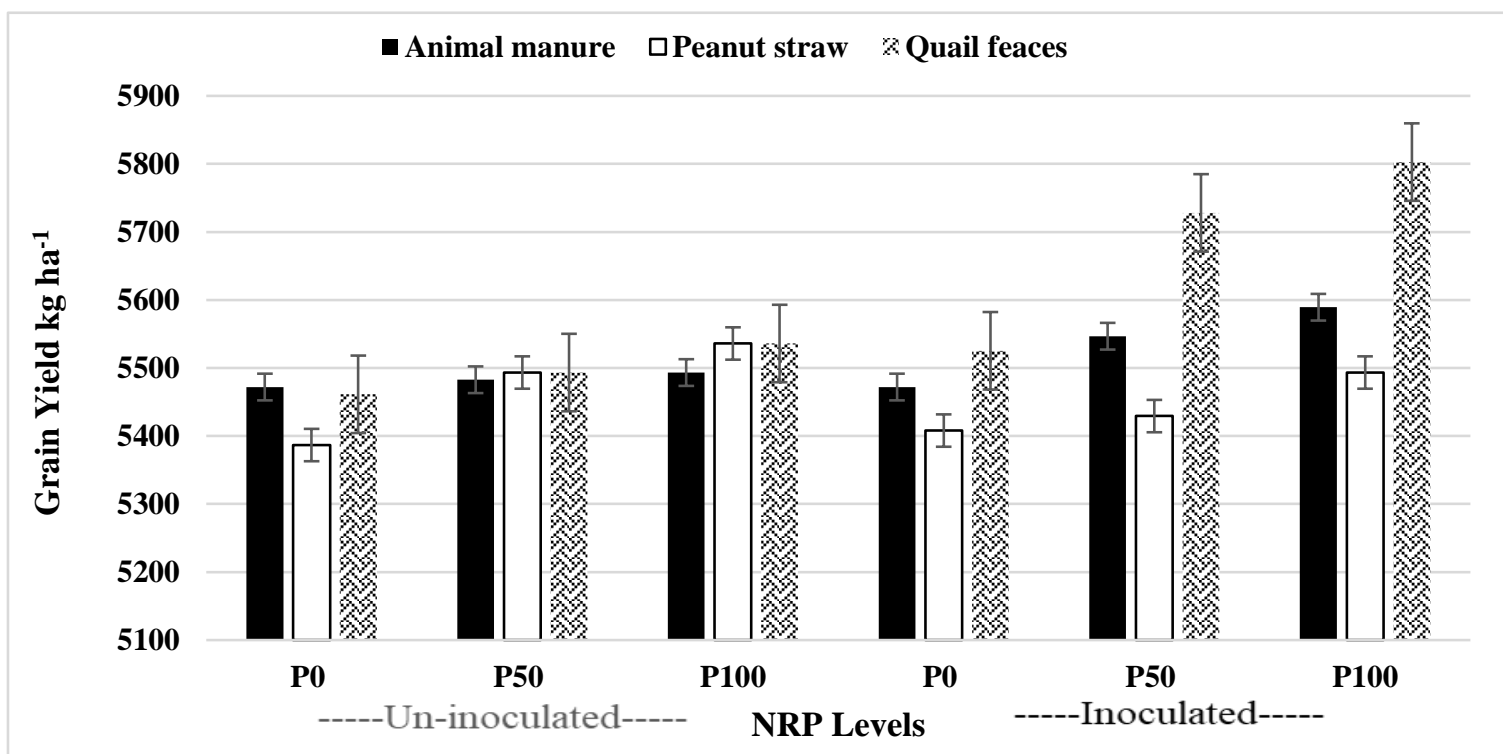

Fig. (1): Effect of Rock-P levels, B. megatherium inoculation and organic sources on grains dry weight $\left(\mathrm{kg} \mathrm{ha}^{-1}\right)$ of wheat plant grown on sand soil

Recently, in comparison with other $\mathrm{P}$ fertilizer sources, Fink et al., [22] found that significantly higher yields of wheat grains were obtained when plants were fertilized with natural rock $\mathrm{P}\left(\mathrm{NP} ; 14 \% \mathrm{P}_{2} \mathrm{O}_{5}\right)$ and monoammonium phosphate (MAP; $48 \% \mathrm{P}_{2} \mathrm{O}_{5}$ ), followed by single superphosphate $\left(\mathrm{SS} ; 18 \% \quad \mathrm{P}_{2} \mathrm{O}_{5}\right)$ and those non fertilized with $\mathrm{P}$, and, finally, wheat plants were fertilized with triple superphosphate (TP; $41 \% \mathrm{P}_{2} \mathrm{O}_{5}$ ). They confirmed the superiority of natural rock phosphate over others. In this respect, Redel et al., [23] explained this phenomenon through the fact that cereals increase the phosphatase acid activity in the soil and become more efficient to uptake $\mathrm{P}$ from the $\mathrm{P}$ fertilizers with low solubility such as rock-P, which could explain our results when NRP was applied to the soil cultivated with wheat crop. These results highlighted the importance of innovative fertilization strategies in improving the efficient use of sparingly soluble phosphate under arid and semi-arid regions. Also, the rate of $\mathrm{P}$ fertilizer plays an important role in enhancing grain yield and this target was achieved [24], and at the same time, they recorded $90 \mathrm{~kg} \mathrm{P} \mathrm{ha}^{-1}$ as an enhancer for growth traits and grain yield $\left(4240.50 \mathrm{~kg} \mathrm{ha}^{-1}\right)$. Their grain yield was, to some extent, lower than the yield resulted from the strategy applied in the recent study, but the effect of $\mathrm{P}$ rates is still consistent with those used in the present study. In addition, they found that using compound microbial fertilizer can improve the content of available $\mathrm{P}$ and $\mathrm{K}$, reflecting an increase of nutrients supply to the plants and improvement of wheat production. A Similar impact of microbial inoculants in improving the sustainability of agricultural systems [25], and modification of plant rhizosphere indicating a good plant performance was documented earlier $[1,26]$. Recently, it was found that the grain yield of bread wheat as affected by press mud (PM), vermicompost (VC) and farmyard manure-FYM), either individually or in combinations, followed the ranking: $\mathrm{VC}>\mathrm{VC}+\mathrm{FYM}>\mathrm{FYM}>\mathrm{PM}+\mathrm{VC}>\mathrm{PM}>$ $\mathrm{PM}+\mathrm{VC}+\mathrm{FYM}>\mathrm{PM}+\mathrm{FYM}$ with $68,66,55,53,38$, 36 , and $30 \%$ increase as compared to the control [27]. Similarly, Billah et al., [28] achieved significant increases in the grain yield of wheat treated with rock-P in the presence of poultry compost either inoculated with Pseudomonas or Proteus species against individuals of rock phosphate, and inorganic phosphorus fertilizer rates. They recorded a highly significant relative increase in the grain yield of inoculated plants over the un-inoculated control. Others explained that bio-compost improved soil properties, growth, and yield of the crops[29]. Chaoui et al., [30] explained that superiority of vermicompost as a useful bio-organic fertilizer may be attributed to its lower $\mathrm{C} / \mathrm{N}$ ratio. Preferability of such bio-organic fertilizer may attribute to its higher content of readily available nutrients and plant growthpromoting substances including auxins, gibberellins, and cytokinins and humic acids [31-33]. In addition, de Jesus Souza ${ }^{[34]}$ clarified that green manure (GM) with jack beans enhanced nutrients status in the soil. Moreover, green manure can ameliorate the soil and modify its chemical reaction [35,36]. According to 
Shirmohammadi et al., [37], bacterial inoculation, especially combined one, in conjunction with $20 \mathrm{~kg} \mathrm{P} \mathrm{ha}^{-1}$ improved plant physiological indices and wheat grain yield. These results are, to some extent, in line with the obtained results. Similarly, Martinez et al., [38] and Cavalliet al.,[39] confirmed the role of soil manuring in improving corn yield. Similar results for corn are recently reported by Marchezan et al., [40], after cattle slurry application to soil. Recent studies on maize crop [41], reflected the positive role of biogas slurry, humic acid, Azotobacter chroococcum, Bacillus circulans and mixture of different AMF spores, and their combinations. This may be attributed to the production of auxin (IAA), and $\mathrm{N}$ fixation, $\mathrm{P}$ and $\mathrm{K}$ mobilization. This explanation was previously established by Abdelfattah et al., [42]; El-Sawah et al., [43]; Afify et al., [44]. Previous studies also indicated that the most potent bacteria could provide nutrients and act as bio-stimulants for plants [45].

\section{Macronutrients uptake by grain}

\section{Nitrogen}

Un-inoculated plants fertilized with rock-P accumulated more $\mathrm{N}$ in grains when supplied with 192 $\mathrm{kg} \mathrm{P} \mathrm{ha}^{-1}$ than those fertilized with $96 \mathrm{~kg} \mathrm{ha}^{-1}$ or those unfertilized $\left(\mathrm{P}_{0}\right)$, but there was no significant difference between the different organic amendments (Fig. 2). Inoculation with $B$. megatherium induced slight increases in $\mathrm{N}$ uptake as compared to the un-inoculated plants. Regarding the differentiation between organic sources, overall means indicated that peanut residues resulted in $\mathrm{N}$ uptake values slightly higher than either quail feces or animal manure. Increasing rock-P levels still have an enhancement effect on increasing $\mathrm{N}$ uptake over the unfertilized or those received $96 \mathrm{~kg} \mathrm{ha}^{-1}$ treatments. Inoculation increased $\mathrm{N}$ uptake by grains by about $8 \%$ over the un-inoculated plants on overall means values. It was also clear that the best $\mathrm{N}$ uptake values were detected under $192 \mathrm{~kg} \mathrm{P} \mathrm{ha}^{-1}$ and seemed true with all organic sources.

\section{Phosphorus}

Phosphorus uptake by grains of the un-inoculated wheat showed varied values according to organic additive source and levels of natural rock $\mathrm{P}$ applied to the soil (Fig. 3). Supply with quail feces had increased $\mathrm{P}$ uptake over those resulted from peanut residues and animal manure applications. These increments were more vigorous under fertilization with $192 \mathrm{~kg} \mathrm{P}^{-1}$ in natural rock-P form. In this regard, quail feces resulted in a relative increase of $\mathrm{P}$ uptake by about $5 \%$ and $15 \%$; $16 \%$ and $19 \% ; 17 \%$ and $4 \%$ over peanut and animal manure for $\mathrm{P}_{0}, \mathrm{P}_{50}$ and $\mathrm{P}_{100}$, respectively. Meanwhile, in general, increasing rock-P levels resulted in the enhancement of $\mathrm{P}$ uptake by grains. The highest values resulted from quail feces applied to the un-inoculated wheat fertilized with $192 \mathrm{~kg} \mathrm{P} \mathrm{ha}{ }^{-1}$ recorded a relative increase in $\mathrm{P}$ uptake by about $24 \%$ and $4 \%$ over the unfertilized control $\left(\mathrm{P}_{0}\right)$ and $\mathrm{P}_{50}$, respectively. The overall means of $\mathrm{P}$ uptake as affected by organic sources and $\mathrm{P}$ levels indicated the superiority of quail feces over peanut and animal manure and at the same time, the level of $192 \mathrm{~kg} \mathrm{P} \mathrm{ha}^{-1}$ compensated more $\mathrm{P}$ derived by grains rather than $\mathrm{P}_{0}$ and $\mathrm{P}_{50}$ levels. The effect of quail feces, in this respect, may be attributed to its $\mathrm{P}$ content and other nutrients in the origin matrix (Table 2).

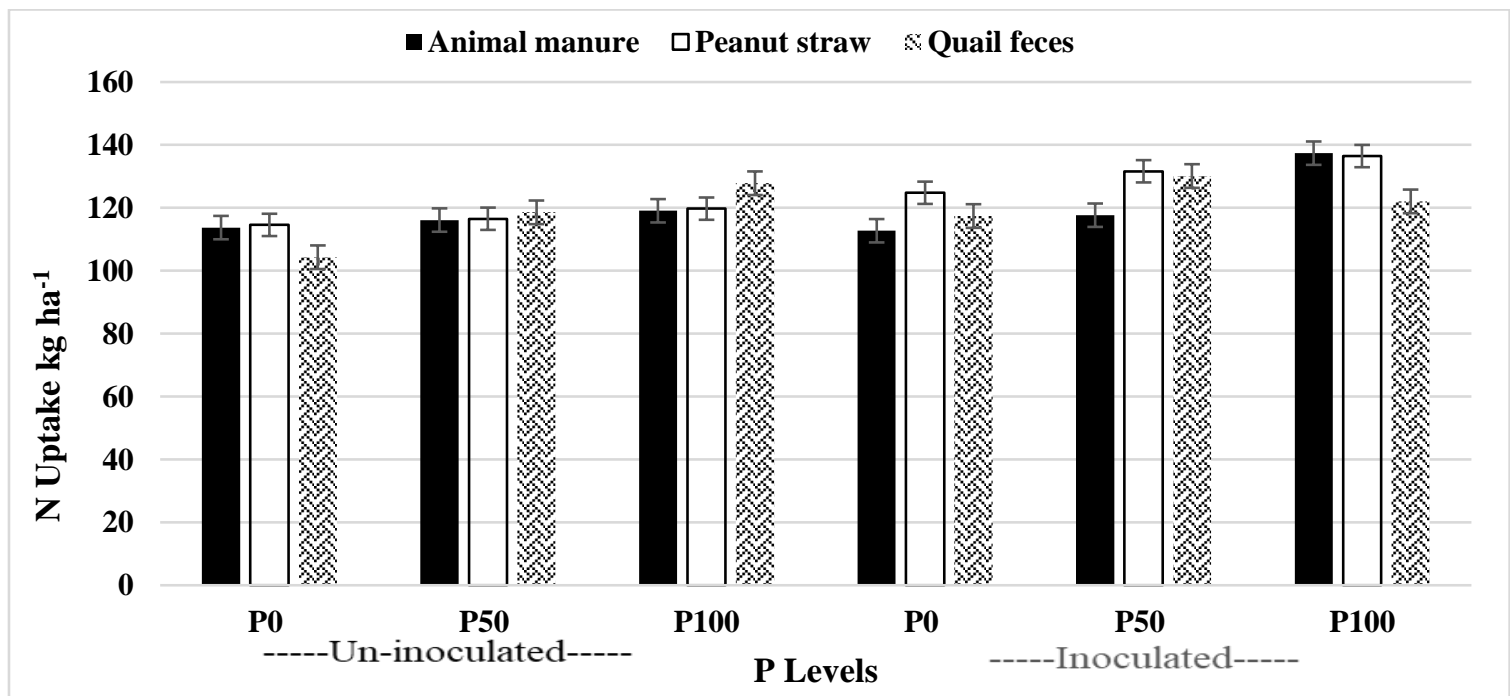

Fig. (2): Effect of Rock-P levels, B. megatherium inoculation and organic sources on $\mathrm{N}$ uptake by grains $\left(\mathrm{kg} \mathrm{ha}^{-1}\right)$ of wheat plant grown on sand soil 
Similar trends, but to some extent, higher were observed in B. megatheruim inoculated plants reflecting the enhancement effect of such bacteria in solubilizing and releasing of either native or organic-P from different sources to the accompanied plant. These results gave the chance to conclude that both tested factors, i.e. organic additives, rock-P levels and bacterial inoculation have a positive significant role in contribution to enriched $P$ nutrient in the soil as well as enhanced its uptake by plants.

\section{Potassium}

Soil supplied with animal manure and peanut residues showed a remarkable decrease in $\mathrm{K}$ uptake in grains of un-inoculated wheat plants fertilized with $96 \mathrm{~kg}$ $\mathrm{P} \mathrm{ha}^{-1}$, while the incorporation of quail feces did not reflect significant difference at the same $\mathrm{P}$ level $\left(\mathrm{P}_{50}\right)$ and the untreated plants $\left(\mathrm{P}_{0}\right)$ (Fig. 4). Only, plants treated with animal manure and fertilized with $192 \mathrm{~kg} \mathrm{P} \mathrm{ha}^{-1}$ showed slight increase in $\mathrm{K}$ accumulated in grains comparing to the unfertilized control, but it increased relatively by about $18 \%$ over plants received $50 \mathrm{~kg} \mathrm{P} \mathrm{ha}^{-1}$. A reversible trend was noticed with plants treated with either peanut residues or quail feces where $\mathrm{K}$ in grains tended to decrease with the highest $\mathrm{P}$ rate application.

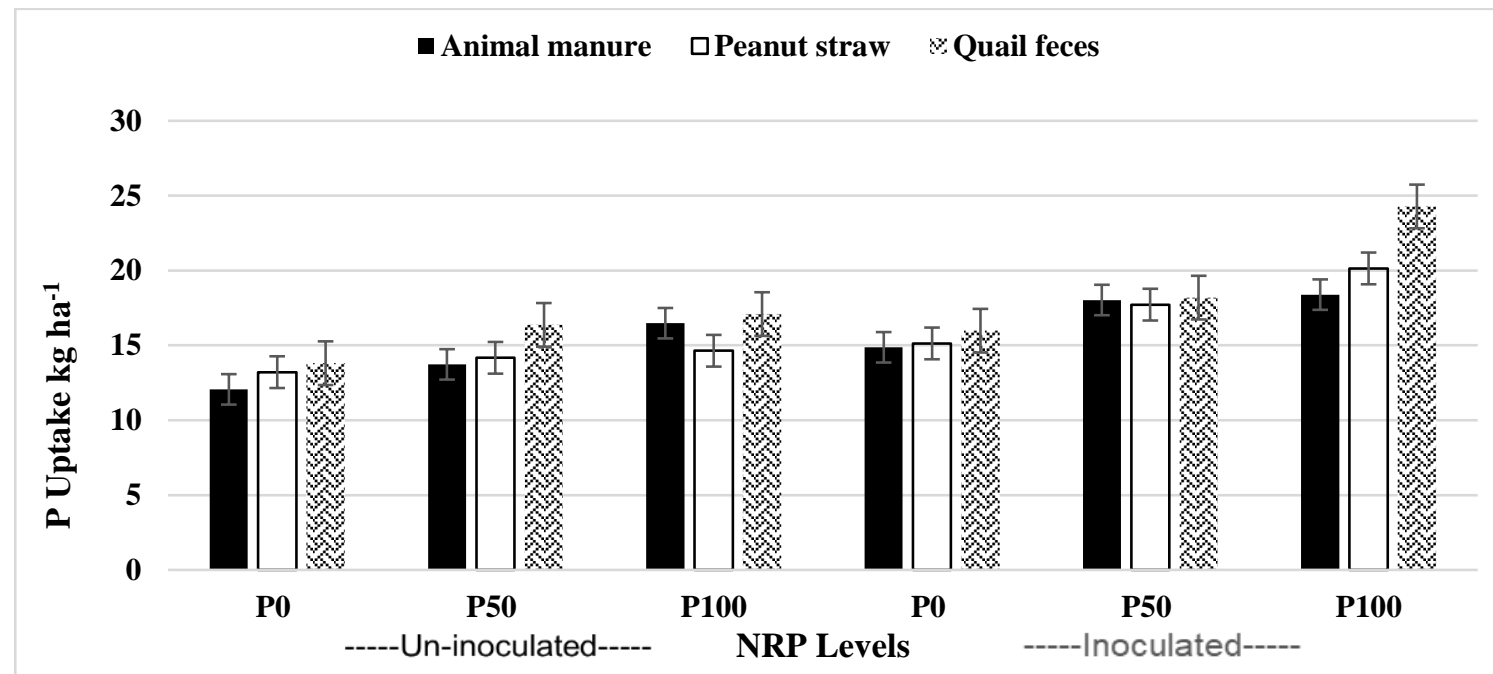

Fig. (3): Effect of Rock-P levels, B. megatherium inoculation and organic sources on $P$ uptake by grains $\left(\mathrm{kg} \mathrm{ha}^{-1}\right)$ of wheat plant grown on sand soil

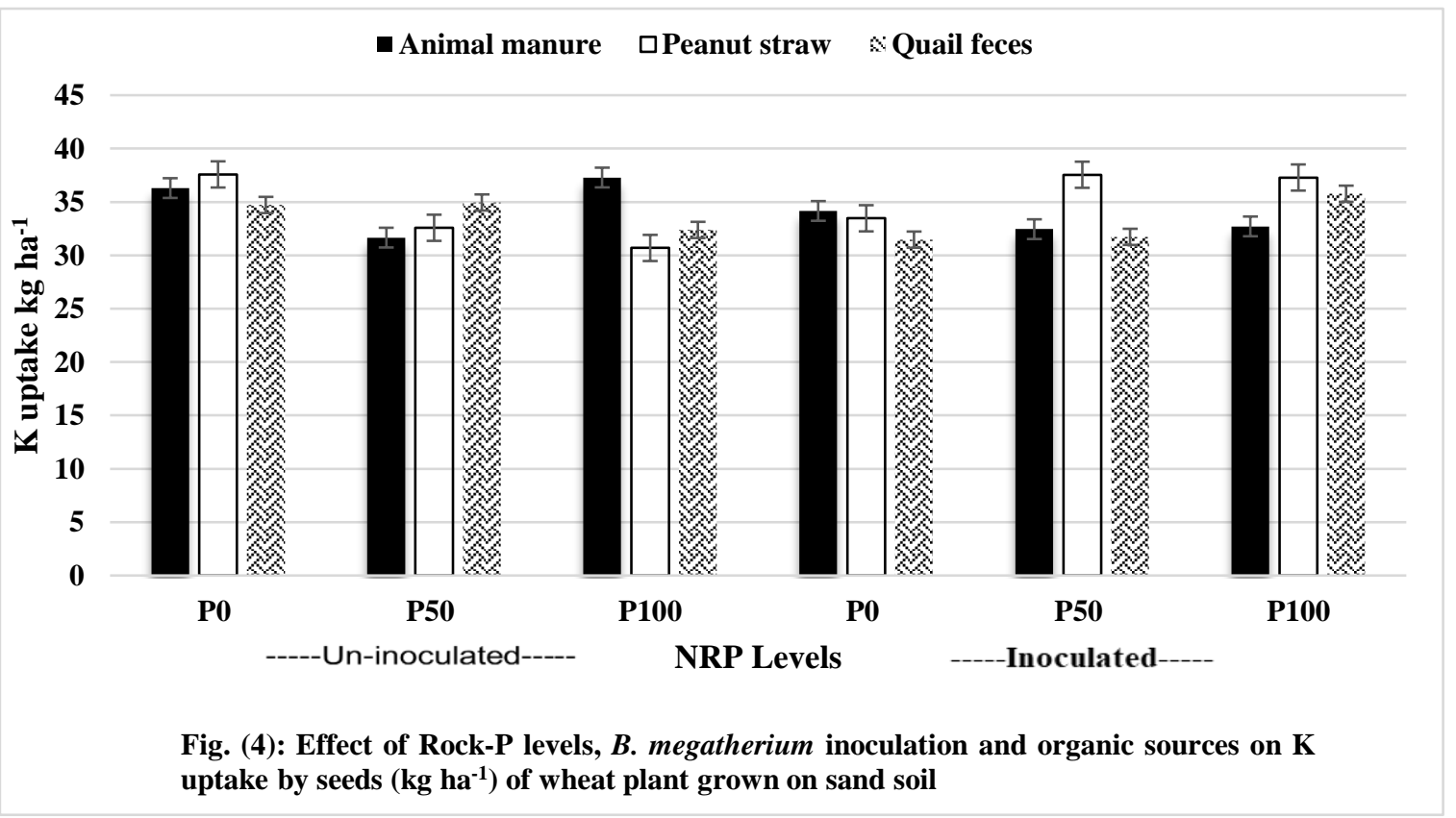


According to the overall means of $\mathrm{K}$ in grains of the un-inoculated wheat, there was no significant difference between the organic residues while it decreased with application of natural rock $\mathrm{P}$ comparable to the unfertilized plants. Inoculated plants reflected the gradual increase in $\mathrm{K}$ accumulated in grains with both $\mathrm{P}$ levels in combination with peanut residues. A similar trend, but to low extent, was observed with plants treated with quail feces, while a reversible trend existed with incorporation of animal manure. In this respect, the overall means of $\mathrm{K}$ uptake by grains of inoculated wheat as affected by organic sources indicated peanut residues superiority over others. Considering the overall means as affected by $\mathrm{P}$ application levels, it seems that high rate $\left(\mathrm{P}_{100}\right)$ resulted in an increase of $\mathrm{K}$ uptake in the grains by about $7 \%$ and $4 \%$ relative to the unfertilized plants $\left(\mathrm{P}_{0}\right)$ and those fertilized with $50 \mathrm{~kg} \mathrm{ha}^{-1}\left(\mathrm{P}_{50}\right)$, respectively. It is worth mentioning that inoculation with B. megatherium had, to somewhat extent, enhanced $\mathrm{K}$ uptake by the grains comparable to the un-inoculated one as indicated by the overall means of plants treated with peanut residues. In comparison, plants fertilized with $192 \mathrm{~kg} \mathrm{P} \mathrm{ha}^{-1}$ combined with either peanut residues or quail feces reflected higher $\mathrm{K}$ accumulated in grains of inoculated plants than the un-inoculated ones.

Earlier, rice residue and cow dung incorporation was found to reduce the quantity of chemical fertilizers [46], which could be associated with increased available nutrient concentrations and urease, alkaline phosphatase, and catalase activities in the top soil [47]. Additionally, Chen et al., [48] revealed that the incorporation of both corn and wheat residues increased carbohydrate-derived components of SOM, with lower indices of aromaticity, alkyl C/O-alkyl C, and hydrophobicity/hydrophilicity than the untreated control. Organic fertilization enhanced soil organic matter (SOM) content, biological activity in biosphere, and soil's physical properties [49-54]. Recently, Samara et al., [55], considered the manure application as organic additive that enhanced $\mathrm{K}$ by $32-81 \%$. However, $\mathrm{P}$, was excessively increased by two to three folds higher than the inorganic fertilization (30-44 mg kg${ }^{-1}$ ). Moreover, Cavalli et al., [39] reported that $\mathrm{N}$ uptake by corn and Italian ryegrass treated with similar amounts of manure and inorganic fertilizer were similar, but higher than the untreated control.

Differentiation between organic residues recently assisted by Erinle and Marschner [56], who clarified the superiority of faba bean residue over either straw additive or un-amended wheat plants when plant $\mathrm{P}$ concentration and $\mathrm{P}$ uptake were considered. They indicated that wheat $\mathrm{P}$ concentration on day 14 was greater with residues than wheat alone, where the $\mathrm{P}$ concentration was 30\% higher with straw and 50\% higher with faba bean residues. They attributed this to the fact that faba bean residue (legume) decomposed more quickly than barley straw (cereal); this could be due to its low C/nutrient ratio [57]. At the same time, decomposing faba bean residue released large amounts of $\mathrm{P}$ which not only increased wheat $\mathrm{P}$ uptake but also $\mathrm{P}$ pools in soil compared with wheat alone and straw amended wheat [58]. Nutrients uptake by maize crop under field conditions of Egypt was enhanced with the application of biogas slurry [59] which can effectively increase soil-N availability and essential macro and micronutrients. Nutrients released from organic sources could improve protein and enzyme synthesis more efficiently than synthetic fertilizers $[60,61]$.

Biofertilization technique can compensate essential nutrients such as $\mathrm{P}$ and $\mathrm{N}$ to plants [13, 62,63], and some microorganisms are also known for releasing organic acids [13], which can promote the acquisition of micronutrients with restricted mobility in the soil, such as $\mathrm{Zn}$ and $\mathrm{Cu}$. Stimulation of root growth leads to a larger area for accessing nutrients [64]. Recently, Abadi et al., [65], found a wide range of PGPB in maize phyllosphere. M. arborescens and S. maltophilia isolates produced indole-3-acetic acid (IAA) and positively affects the growth traits. E. hormaechei showed a marked nitrogenase activity, phosphate solubilization, and IAA production and it was the most effective treatment in improving the uptake of most nutrients. In addition, they indicated that $B$. subtilis and $B$. paralicheniformis had the highest siderophoreproducing capacity that helps in promoting plant growth and consequently $\mathrm{P}$ uptake via phosphate solubilization $[66,67]$. This phenomenon was also reported for bacteria excreting IAA, which leads to enhancing nutrients uptake by inoculated plants $[68,69,41,70]$.

In accordance, Hansen et al., [71] found that inoculation with $P$. bilaiae resulted in increased $\mathrm{P}$ concentrations in wheat root biomass at all $\mathrm{P}$ levels and improved plant nutritional status in low-P soil. Moreover, B. simplex has so far only been shown to increase $\mathrm{N}$ concentrations in the shoot biomass of winter wheat [72] and have the ability to colonize plant roots and promote plant growth [73-75]. 
Under green-house conditions, $\mathrm{P}$ nutrition of Zea mays inoculated with fungi in rock phosphate-amended soil was assessed [76]. More phosphorus became available from rock phosphate due to bacterial inoculation. In line with this, results released from field experiment with maize and alfalfa [77], clarify a little effect of phosphatase enzymes on phosphorus mobilization. The efficiency of the phosphatase enzyme could be enhanced by soil characteristics interacted with microorganisms [78]. Findings by Sun et al., [77] demonstrated the role of root surface area and volume in enhancing plant $\mathrm{P}$ acquisition.

El Mazlouzi et al., [79] indicated that grain P was delivered from other plant organs in addition to one-fifth percentage came from stems, roots and leaves. It seems that aerial parts and roots are considered net source of phosphorus gained by grains. In this respect, leaves seems to be more effective in delivering phosphorus than roots, stems and spikelets, respectively.

\section{${ }^{15} \mathrm{~N} /{ }^{14} \mathrm{~N}$ ratio analysis}

\section{Nitrogen derived from organic sources $-\mathrm{Nd} f_{\text {org }}$}

A portion of nitrogen derived from organic sources in grain was higher from animal manure than those derived from peanut and quail feces. This phenomenon was more vigorous with the application of rock-P at different levels (Fig. 5). In case of peanut straw and quail feces, percentage and absolute values of Ndforg were slightly decreased with the application of rock-P at both levels comparable to the unfertilized control. Inoculated plants showed a decline in Ndforg with rock-P fertilization especially at rate of $192 \mathrm{~kg} \mathrm{ha}^{-1}$. Mean values of Ndforg from animal manure were negatively affected by inoculation as compared to those of the un-inoculated plants. A reversible trend was noticed with both of peanut straw and quail feces. In this respect, application of peanut straw and quail feces induced a relative increase in Ndforg, on mean average basis, by about $19 \%$ and $16 \%$, respectively over the un-inoculated plants. High rate of rock-P, especially when combined with peanut straw and quail feces, minimized the quantity of $\mathrm{N}$ derived from these sources to either inoculated or the un-inoculated plants. It is worthy to note that higher $\mathrm{N}$ was derived from animal manure than others to the un-inoculated plants while peanut straw was the best source derived releasing $\mathrm{N}$ to the inoculated plants.

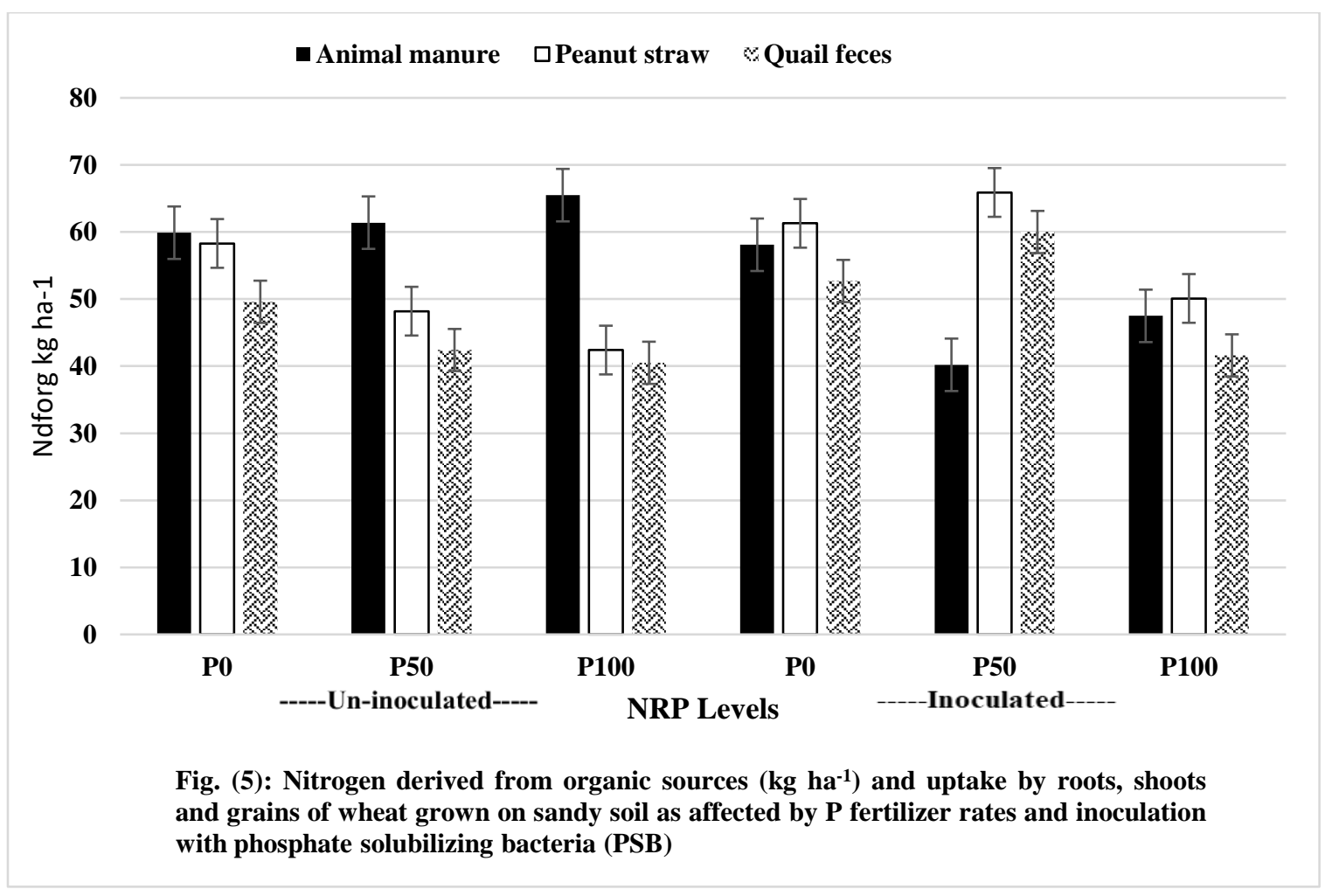




\section{$N$ use efficiency of organic and mineral-N}

The un-inoculated plants were efficiently used $\mathrm{N}$ derived from animal manure which was enhanced with increasing rock-P levels. Reversibly, the Org-NUE\% of peanut straw and quail feces tended to decrease with increasing rock-P rates (Fig. 6). These Org-NUE\% of peanut straw and quail feces were lower than those of animal manure added to the un-inoculated plants. The NUE\% of urea, in general, was severely lower than Org-NUE\%, but seems to be enhanced by increasing rock-P rates.

In this regard, the highest NUE\% of urea was detected with $192 \mathrm{~kg} \mathrm{P} \mathrm{ha}{ }^{-1}$ level. Variation in urea NUE\% was affected by the accompanied organic source. Both of urea NUE\% and Org-NUE\% of animal manure tended to decrease with increasing rock-P rates. Those of peanut straw and quail feces showed a reversible trend where they increased with increasing rock-P levels. Efficient use of $\mathrm{N}$ derived from peanut straw and quail feces as well as urea by inoculated plants was slightly increased under all rock-P levels over those of the un-inoculated plants. On the other hand, animal manure NUE\% was decreased in inoculated plants comparable to the un-inoculated ones.

Results after Ismail and Moursy [80] were partially consistent with us where they found NUE \% by wheat grains tended to be enhanced by combined treatment of chemical ammonium sulfate $25 \%$ plus $25 \%$ chicken manure under inoculation with Azotobacter chrooccum recording $34 \%$.

\section{Nitrogen remained in soil after harvest $-N_{\text {rem }}$}

Fertilizer-N, remained in soil after wheat harvest as affected by different tested factors, does not exceed $6 \%$ of the total $\mathrm{N}$ added (Fig. 7). Under the un-inoculation condition, $\mathrm{N}$ remained in soil after quail feces and peanut straw treatment were higher than those detected with animal manure treatment. These values, generally, were increased with increasing rock-P levels up to $192 \mathrm{~kg} \mathrm{P} \mathrm{ha}^{-1}$. Similar trends were noticed in the soil under the inoculated plants. Values of $\mathrm{N}$, remained in soil after harvest of inoculated plants, were significantly higher than those recorded with the un-inoculated plants. This was true with all organic sources and rock-P levels.

\section{Fertilizer - N Balance}

Urea fertilizer was added in combination with different organic sources only in field micro-plot enriched with ${ }^{15} \mathrm{~N}$ to follow up the fate of such form and indirectly distinguished the fractions of $\mathrm{N}$ derived to wheat plants from the different sources. Balance of $\mathrm{N}$ derived from urea either by plant or budget remained in soil after harvest revealed that low portion of $\mathrm{N}$ from fertilizer was taken up by plants in addition to low quantity remained in soil under plants unfertilized with rock-P fertilizer and consequently high portion of fertilizer was lost from soil media (Table 3 ). This was true under all organic sources applied to the un-inoculated plants. On the other hand, increasing rock-P rates added to the un-inoculated plants resulted in enhancement of Ndff by plants and also, the fraction remained in soil which caused more reduction in portion of $\mathrm{N}$ losses. Rate of $192 \mathrm{~kg} \mathrm{P} \mathrm{ha-1}$ induced the highest reduction in $\mathrm{N}$ losses. In this regard, lower $\mathrm{N}$ losses were noticed with quail feces treatment than those recorded under peanut straw and animal manure, respectively.

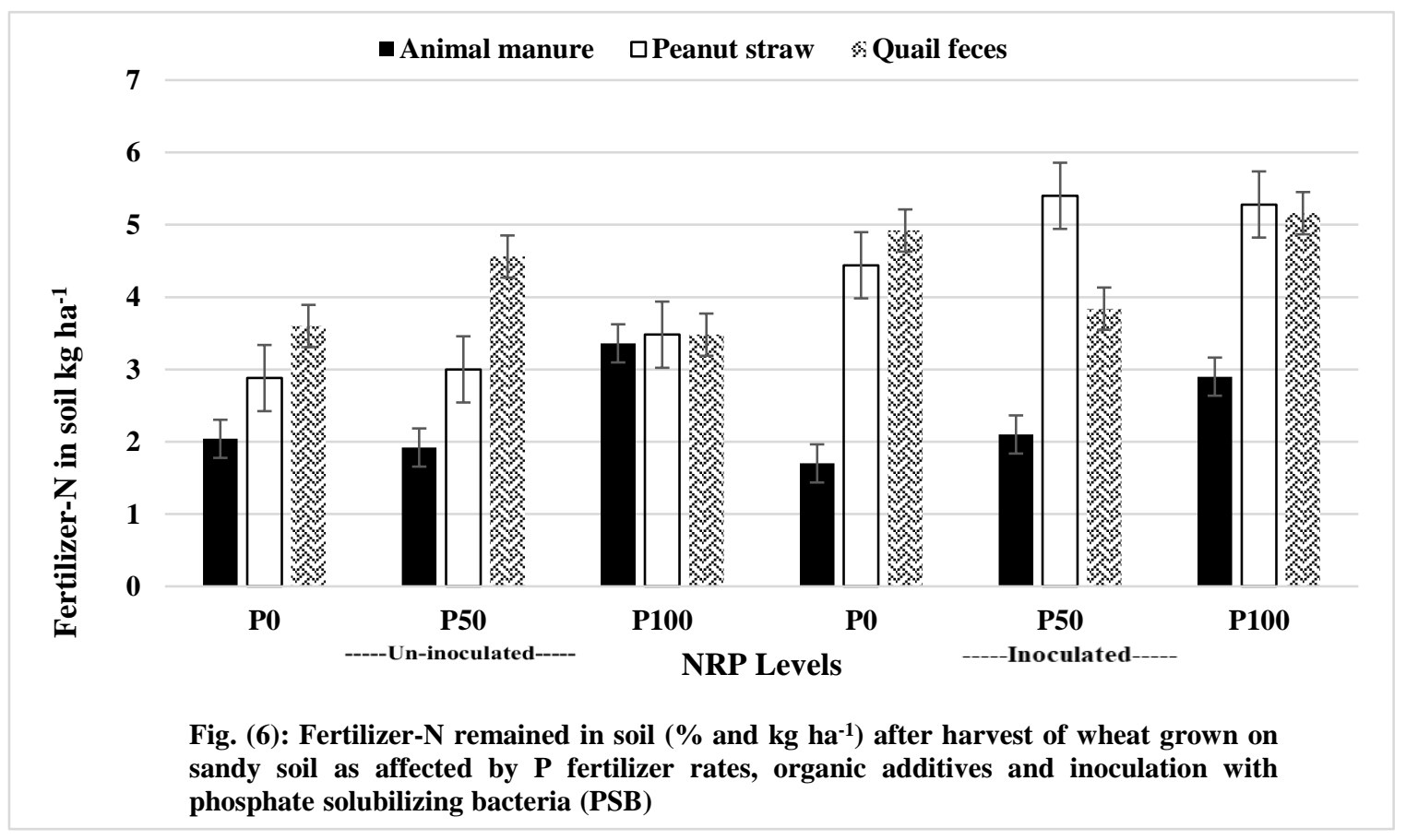

Arab J. Nucl. Sci. Appl., Vol. 54, 4, (2021) 


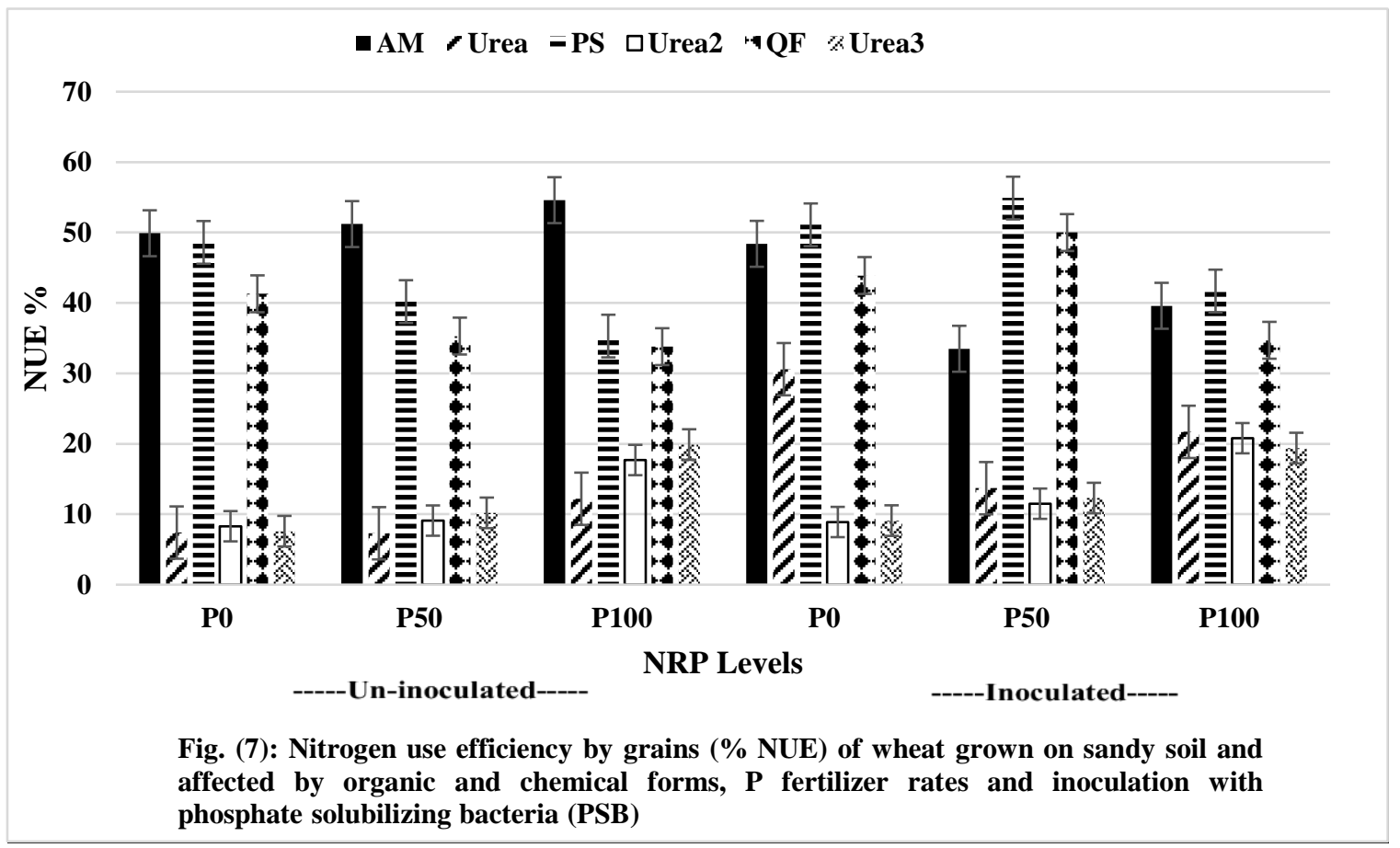

TABLE (3): Fertilizer nitrogen balance $\left(\mathrm{kg} \mathrm{ha}^{-1}\right)$ as affected by $B$. megatherium inoculation, rock-P levels and different organic additives

\begin{tabular}{|c|c|c|c|c|c|c|c|c|c|c|}
\hline \multirow{4}{*}{ Inoc. } & \multirow{4}{*}{$\underset{\mathrm{kg} \mathrm{ha}^{-1}}{P}$} & \multicolumn{9}{|c|}{ Nitrogen fertilization } \\
\hline & & \multicolumn{3}{|c|}{ Animal manure } & \multicolumn{3}{|c|}{ Peanut straw } & \multicolumn{3}{|c|}{ Quail feces } \\
\hline & & \multicolumn{9}{|c|}{ Nitrogen derivation } \\
\hline & & $\dagger$ NffPL & $\dagger \dagger$ Nsoil & \$NLoss & NffPL & Nsoil & NLoss & NffPL & Nsoil & NLoss \\
\hline \multirow{3}{*}{ Un-inoc } & $\mathbf{P}_{0}$ & $11.42 \mathrm{c}$ & $2.04 \mathrm{~b}$ & $106.6 \mathrm{a}$ & $12.90 \mathrm{~d}$ & $2.88 \mathrm{c}$ & $104.2 \mathrm{a}$ & $13.80 \mathrm{de}$ & $3.60 \mathrm{~b}$ & $102.6 \mathrm{a}$ \\
\hline & $\mathbf{P}_{50}$ & $13.68 \mathrm{c}$ & $1.92 \mathrm{c}$ & $104.4 \mathrm{a}$ & $16.70 \mathrm{c}$ & $3.00 \mathrm{c}$ & $100.3 \mathrm{a}$ & $18.80 \mathrm{~d}$ & $4.56 \mathrm{a}$ & $96.6 \mathrm{ab}$ \\
\hline & $\mathbf{P}_{100}$ & $20.50 b$ & $3.36 \mathrm{a}$ & $96.1 \mathrm{~b}$ & $29.70 b$ & $3.48 \mathrm{~b}$ & $86.8 b$ & $35.00 \mathrm{~b}$ & $3.48 \mathrm{~b}$ & $81.5 b$ \\
\hline \multirow{3}{*}{ Inoc } & $\mathbf{P}_{0}$ & $39.20 \mathrm{a}$ & $2.04 \mathrm{~b}$ & $78.8 \mathrm{c}$ & $13.90 \mathrm{~d}$ & $4.44 \mathrm{~b}$ & $101.7 \mathrm{a}$ & $16.00 \mathrm{~d}$ & $4.92 \mathrm{a}$ & $99.1 \mathrm{ab}$ \\
\hline & $\mathbf{P}_{50}$ & $26.50 \mathrm{~b}$ & $2.52 b$ & $91.0 \mathrm{~b}$ & $28.70 \mathrm{~b}$ & $5.40 \mathrm{a}$ & $85.9 b$ & $26.70 \mathrm{c}$ & $3.84 \mathrm{~b}$ & $89.5 b$ \\
\hline & $\mathbf{P}_{100}$ & $38.00 \mathrm{a}$ & $3.48 \mathrm{a}$ & $78.5 \mathrm{c}$ & $38.50 \mathrm{a}$ & $5.28 \mathrm{a}$ & $76.2 b$ & $41.50 \mathrm{a}$ & $5.16 \mathrm{a}$ & $73.3 \mathrm{c}$ \\
\hline
\end{tabular}

$\uparrow \mathrm{NffPL}, \mathrm{N}$ derived by whole plant from fertilizer; $\dagger \uparrow$ Nsoil, $\mathrm{N}$ remained after harvest; $\$$ Nloss, $\mathrm{N}$ lost from soil

Values in the same column followed by the same letter are not significantly different at $P \leq 0.05$.

Plants inoculated with $B$. megatherium reflected higher $\mathrm{N}$ derived from urea and increased with increasing rock-P rates while the portion of $\mathrm{N}$ losses tended to decrease significantly as compared to the un-inoculated plants treated with animal manure. Similar trends were observed under treatments of peanut straw and quail feces. In conclusion, inoculation with B. megatherium and increasing rock-P rates resulted in increasing the portion of $\mathrm{N}$ derived from urea by plants and, at the same time reduced the $\mathrm{N}$ portion lost from soil media by any mechanism. The authors think that organic treated plants were more dependent on fraction $\mathrm{N}$ derived from organic form rather than chemical
$\mathrm{N}$ form (urea). There was no significant difference between organic sources when $\mathrm{N}$ losses were considered.

In this regard, Soliman [81] pointed out that the application of medium to low mineral $\mathrm{N}$ combined with $\mathrm{n}$ organic compost lowered the portion of $\mathrm{N}$ losses and achieved positive $\mathrm{N}$ balance. This phenomenon was more vigorous with combined treatment of $75 \%$ mineral plus $25 \%$ organic compost under the un-inoculated wheat. They observed negative $\mathrm{N}$ balance when mineral nitrogen was added individually and tended to decline with reduce in nitrogen fertilizer rates. The un-inoculated plants showed lower $\mathrm{N}$ losses than inoculated ones. 
Data released from a pot experiment after Ding et al.,[82], with the application of ${ }^{15} \mathrm{~N}$ technique indicated that an average of $31.4 \%$ wheat $\mathrm{N}$ uptake was derived from urea, $9.2 \%$ from maize residue, and $59.5 \%$ from the soil in the first season. To some extent, these results are inconsistent with those obtained in the present study. In addition, they indicated that maize residue compensated lower percent (0.3-4.8\% and 3.1-13.2\%) of nitrogen retained in soil mineral and microbial biomass $\mathrm{N}$, respectively, than urea (1.0-4.2\% and 4.6-16.8\%). Additionally, $35.9 \%$ and $16.9 \%$ of urea- ${ }^{15} \mathrm{~N}$ and residue${ }^{15} \mathrm{~N}$ were recovered by wheat, $28.1 \%$ and $46.9 \%$ remained in the soil, and $36.0 \%$ and $36.2 \%$ were lost. Urea application resulted in a higher $\mathrm{N}$ uptake and $\mathrm{N}$ recovery efficiency than that of residue- $\mathrm{N}$ with increasing proportion of topdressing N. Substituting $25 \%$ mineral $\mathrm{N}$ with manure decreased the urea- ${ }^{15} \mathrm{~N}$ loss without negative effects on crop dry matter and $\mathrm{N}$ uptake. In line with us, they recorded nearly close percentages of residual urea- ${ }^{15} \mathrm{~N}$ and maize residue- ${ }^{15} \mathrm{~N}$ accounted for $3.9 \%$ and $3.0 \%$, respectively. Furthermore, they accounted about $29.3 \%$ of residue- ${ }^{15} \mathrm{~N}$ and $18.6 \%$ of urea- ${ }^{15} \mathrm{~N}$ remained in the soil after the second season. They suggested that fertilizer and crop residue were actively involved in soil $\mathrm{N}$ transformation and plant $\mathrm{N}$ nutrition, emphasizing the capacities of organic residues to sustainably supply nutrients.

In another field ${ }^{15} \mathrm{~N}$ micro-plot experiment, Chen et al., [83] revealed that the portion of nitrogen gained from fertilizer (Ndff), was correlated to the rate of nitrogen fertilizer addition while those derived from soil were not affected. Both fertilizer- $\mathrm{N}$ recovery and $\mathrm{N}$ loss were found to be affected by application methods. Fertilizer nitrogen, remained in soil accounted for $31-51 \%$, was adversely correlated with nitrogen application rates. Another data after Chen et al., [84] revealed that nitrogen recovered from labelled urea was affected by methods of application. Most of the soil residual $\mathrm{N}$ was retained in the $0-20 \mathrm{~cm}$ soil layer.

Dealing with the effect of organic amendments on efficient use of nitrogen fertilizer, recent work conducted by Piccoli et al., [85] indicated an increase of NUE due to the addition of poultry manure to residues in winter wheat. This phenomenon is, to some extent, in line with us, but we found increase in NUE with increasing $P$ levels. They attributed the higher efficiency of manure on winter wheat to temporal proximity coupled with the lower temperature during the growing season. Inconsistent with us, they found organic additives resulted in far lower NUEs than those of mineral fertilizer. In addition, the present results refute those after Omara et al., [86] who recorded significantly lower uptake efficiency of manure $\mathrm{N}$ as compared to inorganic $\mathrm{N}$. They concluded that despite the low $\mathrm{N}$ uptake efficiency, animal manure can produce a similar yield to that produced by inorganic $\mathrm{N}$ fertilizer.

\section{CONCLUSION}

Organic fertilizers recently are considered a vital and proper solution and promising strategy used to provide nutrients to the soil and subsequently to grown plants. Besides, this technology has an important role in building up the poor and loose soil to introduce it into productive sustainable agricultural systems. The use of different organic sources in this study reflected an effective role on improving wheat production under poor sandy soil conditions. Animal manure, peanut straw, and quail feces have a positive effect in increasing the grain yield of wheat over the untreated control. Also, increased $\mathrm{P}$ fertilizer levels enhanced the production of wheat grain yield. A similar trend was noticed with inoculated plants compared to the un-inoculated plants. Nutrients uptake was also enhanced by the addition of organic sources as sole sources for wheat nutrition and its values were increased with increasing $\mathrm{P}$ fertilizer rates up to $192 \mathrm{~kg}$ $\mathrm{ha}^{-1}$. These organic sources compensated considerable amounts of nitrogen, phosphorus, and potassium nutrients in grains. Application of $192 \mathrm{~kg} \mathrm{P} \mathrm{ha}$ positively improved the nutritional value of wheat. ${ }^{15} \mathrm{~N}$ technique revealed that remarkable values of $\mathrm{N}$ were derived from organic sources and minimized the dependence on chemical form. Increasing $\mathrm{P}$ rates enhanced Ndff and reduced the $\mathrm{N}$ losses from soil media. Efficient use of $\mathrm{N}$ derived from organic sources was enhanced by increasing $\mathrm{P}$ rates and $B$. megatherium inoculation.

\section{REFERENCES}

[1]Vessey, J.K. (2003). Plant growth promoting rhizobacteria as biofertilizers. Plant Soil 255, 571586.

[2]Berger, L.R., Stamford, N.P., Santos, C.E.R.S., Freitas, A.D.S., Franco, L.O., and Stamford, T.C.M. (2013). Plant and soil characteristics affected by biofertilizers from rocks and organic matter inoculated with diazotrophic bacteria and fungi that produce chitosan. J Soil Sci Pl Nutr 13 (3), 592-603.

[3]Kumar, V. and Ahlawat, I.P.S. (2004). Carry-over effect of biofertilizers and nitrogen applied to wheat (Triticum aestivum) and direct applied $\mathrm{N}$ in maize (Zea mays) in wheat maize cropping systems. Indian Journal of Agronomy. 49 (4), 233-236. 
[4]Kumar, A. and Urmila (2018). Impact of biofertilizers in enhancing growth and productivity of wheat: A review. International Journal of Chemical Studies, 6 (4), 360-362.

[5]Chondie, Y.G. (2015). Effect of integrated nutrient management on wheat: A Review. Journal of Biology, Agriculture and Healthcare, 13 (5), 68-76.

[6]Elser, J.J. (2012). Phosphorus: a limiting nutrient for humanity? Curr Opin Biotechnol 23, 833-838.

[7]Gasparatos, D., Haidouti, C., Haroulis, A. and Tsaousidou, P. (2006). Estimation of phosphorus status of soil Fe-enriched concretions with the acid ammonium oxalate method. Commun Soil Sci Plant 37, 2375-2387.

[8]Cordell, D. and White, S. (2014). Life's bottleneck: sustaining the world's phosphorus for a Food secure future. Annu Rev Environ Resour 39 (1), 161-188.

[9]Veneklaas, E.J., Lambers, H., Bragg, J., Finnegan, P.M., Lovelock, C.E., Plaxton, W.C., Price, C.A., Scheible, W.R., Shane, M.W., White, P.J. and Raven, J.A. (2012). Opportunities for improving phosphorususe efficiency in crop plants. Phytol 195(2):306-320.

[10]Yu, K., Chen, X., Pan, G., Zhang, X., and Chen, C. (2016). Dynamics of soil available phosphorus and its impact factors under simulated climate change in typical farmland of Taihu Lake region, China. Environ Monit Assess 188, 1-8.

[11]Ipsilantis, I., Karamesouti, M. and Gasparatos, D. (2018). Beneficial Microorganisms for the Management of Soil Phosphorus. In: E. Lichtfouse (ed.), Sustainable Agriculture Reviews 32, Springer Nature Switzerland AG 2018, p.53-75.

[12]Adhya, T.K., Kumar, N., Reddy, G., Podile, A.R., Bee, H., and Samantaray, B. (2015). Microbial mobilization of soil phosphorus and sustainable $\mathrm{P}$ management in agricultural soils. Curr Sci 108, 1280-1287.

[13]Sharma, A., Johri, B.N., Sharma, A.K. and Glick, B.R. (2003). Plant growth promoting bacterium Pseudomonas sp. strain GRP3 influences iron acquisition in mung bean (Vigna radiata $\mathrm{L}$. Wilzeck). Soil Biol Biochem 35, 887-894.

[14]Owen, D., Williams, A.P., Griffith, G.W. and Withers, P.J.A. (2015). Use of commercial bioinoculants to increase agricultural production through improved phosphorus acquisition. Appl Soil Ecol 86, 41-54.
[15]Rashid, M.I., Mujawar, L.H., Shahzad, T., Almeelbi, T., Ismail, I.M. and Oves, M. (2016). Bacteria and fungi can contribute to nutrients bioavailability and aggregate formation in degraded soils. Microbiol Res $183,26-41$.

[16]Abd El-Hamid, A. R., AL-Kamar, F. A. A. and Husein, M.E. (2013). Impact of some organic and biofertilizers soil amendments on the fertility status, some soil properties, and productivity of sandy soils. J. Soil Sci. and Agric. Eng., Mansoura Univ., Vol. 4 (10), 989-1007.

[17]Carter, M. R. and Gregorich, E. G. (2008). Soil sampling and methods of analysis. 2 nd ed. CRC, bocaratan, FL. 1224 pp.

[18]Estefan, G.; Sommer, R. and Ryan, J. (2013). Methods of soil, plant and water analysis: A manual for the West Asia and North Africa regions. International Center for Agricultural Research in the Dry Areas (ICARDA), $3^{\text {rd }} \mathrm{Ed}$.

[19]IAEA, Vienna (2001). Use of isotope and radiation methods in soil and water management and crop nutrition. Manual Training Course Series No.14. IAEA, Vienna.

[20]SAS (2002). The SAS System for Windows. Release 9. 0. SAS Inst. Inc., Cary, NC.

[21]Yang, W., Gong, T., Wang, J., Li, G., Liu, Y., Zhen, J., Ning, M., Yue, D., Du, Z. and Chen, G. (2020). Effects of Compound Microbial Fertilizer on Soil Characteristics and Yield of Wheat (Triticum aestivum L.). J Soil Sci Pl Nutr 20, 2740-2748.

[22]Fink, J., Borga, G., Frosi, G., Junior, C. P., Pitta, C. S. R. and Sánchez-Rodríguez, A. R. (2020). Enhancing wheat and soybean yields in a subtropical oxisol through effective P fertilization strategies. $J$ Soil Sci Plant Nutr 20, 1605-1613.

[23]Redel, Y., Staunton, S., Durán, P., Gianfreda, L., Rumpel, C. and Luz Mora, M. (2019). Fertilizer P uptake determined by soil $\mathrm{P}$ fractionation and phosphatase activity. J Soil Sci Pl Nutr 19, 166-174.

[24]Noonari, S., Kalhoro, S.A., Ali, A., Mahar, A., Raza, S., Ahmed, M., Shah, S.F.A. and Baloch, S.U. (2016). Effect of different levels of phosphorus and method of application on the growth and yield of wheat. Natural Science, 8, 305-314.

[25]Calvo, P., Nelson, L., and Kloepper, J.W. (2014). Agricultural uses of plant biostimulants. Plant Soil 383, 3-41. 
[26]Adesemoye, A.O., and Kloepper, J.W. (2009). Plantmicrobes interactions in enhanced fertilizer-use efficiency. Appl Microbiol Biotechnol 85,1-12.

[27]Ali, N., Khan, M. N., Ashraf, M. S., Ijaz, S., Saeedur-Rehman, H., Abdullah, M., Ahmad, N., Akram, H. M. and Farooq, M. (2020). Influence of different organic manures and their combinations on productivity and quality of bread wheat. $J$ Soil Sci Pl Nutr 20, 1949-1960.

[28]Billah, M., Khan, M., Bano, A., Nisa, S., Hussain, A., Dawar, K. M., Munir, A. and Khan, N. (2020). Rock phosphate-enriched compost in combination with rhizobacteria; a cost-effective source for better soil health and wheat (Triticum aestivum) productivity. Agronomy, 10, 1390; doi: 10.3390/agronomy10091390

[29]Pezeshkpour, P., Ardakani, M.R., Paknejad, F. and Vazan, S. (2014). Effects of Vermicompost, mycorrhizal symbiosis and biophosphate solubilizing bacteria on seed yield and quality of chickpea as autumn plantation in rain fed conditions. Bull Environ Pharmacol Life Sci 3, 53-58.

[30]Chaoui, H.I., Zibilske, L.M., and Ohno, T. (2003). Effects of earthworm casts and compost on soil microbial activity and plant nutrient availability. Soil Biol Biochem 35, 295-302.

[31]Prabha, M.L. (2009). Waste management by vermitechnology. Indian J Environ Protect 29, 795800 .

[32]Jat, R.S. and Ahlawat, I.P.S. (2006). Direct and residual effect of vermicompost, biofertilizers and phosphorus on soil nutrient dynamics and productivity of chickpea-fodder maize sequence. $J$ Sustain Agric 28, 41-54.

[33]Singh, R., Sharma, R.R., Kumar, S., Gupta, R.K. and Patil, R.T. (2008). Vermicompost substitution influences growth, physiological disorders, fruit yield and quality of strawberry (Fragaria $\mathrm{x}$ ananassa Duch.). Bioresour Technol 99, 8507-8511.

[34]de Jesus Souza, B., Lopes do Carmo, D., Santos, R. H. S., de Oliveira, T. S. and Fernandes, R. B. A. (2019). Residual Contribution of Green Manure to Humic Fractions and Soil Fertility. J of Soil Sci Pl Nutr 19, 878-886.

[35]Mendonça, E.S., Rowell, D.L., Martins, A.G. and Silva, A.P. (2006). Effect of $\mathrm{pH}$ on the development of acidic sites in clayey and sandy loam oxisol from the Cerrado Region, Brazil. Geoderma 132, 131142.
[36]Tejada, M., Gómez, I., Hernández, T. and Garcia, C. (2010). Response of Eisenia fetida to the application of different organic wastes in an aluminium contaminated soil. Ecotoxicol Environ Saf 73, 19441949.

[37]Shirmohammadi, E., Alikhani, H. A., Pourbabaei, A. A. and Etesami, H. (2020). Improved phosphorus (P) uptake and yield of rainfed wheat fed with $\mathrm{P}$ fertilizer by drought-tolerant phosphate-solubilizing fluorescent Pseudomonads strains: a field study in drylands. J Soil Sci Pl Nutr 20, 2195-2211.

[38]Martinez, E., Domingo, F., Rosello, A., Serra, J., Boixadera, J. and Lloveras, J. (2017). The effects of dairy cattle manure and mineral $\mathrm{N}$ fertilizer on irrigated maize and soil $\mathrm{N}$ and organic C. Eur $J$ Agron 83, 78-85.

[39]Cavalli, D., Cabassi, G., Borrelli, L., Geromel, G., Bechini, L., Degano, L., and Gallina, P.M. (2016). Nitrogen fertilizer replacement value of undigested liquid cattle manure and digestates. Eur J Agron 73, $34-41$.

[40]Marchezan, C., Ferreira, P.A.A., Silva, L.S., Bacca, A., Krug, A.V., Nicoloso, F.T., Tarouco, C.P., Tiecher, T.L., Brunetto, G. and Ceretta, C.A. (2020). Nitrogen availability and physiological response of corn after 12 years with organic and mineral fertilization. $J$ Soil Sci Pl Nutr. https://doi. org/10.1007/s42729-020-00185-2

[41]Gao, J., Luo, Y., Wei, Y., Huang, Y., Zhang, H., He, W., Sheng, H. and An, L. (2019). Screening of plant growth promoting bacteria (PGPB) from rhizosphere and bulk soil of Caragana microphylla in different habitats and their effects on the growth of Arabidopsis seedlings. Biotechnol Equip 33, 921930.

[42]Abdel-fattah, G.M., Asrar, A.A., Al-amri, S.M. and Abdel-salam, E.M. (2014). Influence of arbuscular mycorrhiza and phosphorus fertilization on the gas exchange, growth and phosphatase activity of soybean (Glycine $\max$ L.) plants. Photosynthetica, $52,581-588$.

[43]El-Sawah, A.M., Hauka, F.I.A. and Afify Aida, H. (2018). Dual inoculation with Azotobacter chroococcum MF135558 and Klebsiella oxytoca MF135559 enhance the growth and yield of wheat plant and reduce N-fertilizers usage. J. Food Dairy Sci., 10, 67-76.

[44]Afify, A.H., Hauka, F.I.A. and El-Sawah, A.M. (2018). Plant Growth-Promoting Rhizobacteria 
enhance Onion (Allium cepa L.) productivity and minimize requisite chemical fertilization. Env. Biodiv. Soil Secur., 2, 119-129.

[45]Jha, C.K. and Saraf, M. (2012). Evaluation of multispecies plant-growth promoting consortia for the growth promotion of Jatropha curcas L. J. Plant Growth Regul., 31, 588-598.

[46]Sfez, S., De Meester, S. and Dewulf, J. (2017). Codigestion of rice straw and cow dung to supply cooking fuel and fertilizers in rural India: impact on human health, resource flows and climate change. Sci Total Environ 609:1600-1615.

[47]Zhang Li, W.J., Fu, G. and Zhao, Y. (2018). Rotary tillage in rotation with plowing tillage improves soil properties and crop yield in a wheat-maize cropping system. PLoS One 13 (6), e0198193.

[48]Chen, X., Mao, A., Zhang, Y., Zhang, L., Chang, J., Gao, H., and Thompson, M.L. (2017). Carbon

and nitrogen forms in soil organic matter influenced by incorporated wheat and corn residues. J Soil Sci Pl Nutr 63, 377-387.

[49]Fabrizzi, K.P., García, F.O., Costa, J.L. and Picone, L.I. (2005). Soil water dynamics, physical properties and corn wheat responses to minimum and no tillage systems in the southern Pampas of Argentina. Soil Tillage Res 81, 57-69.

[50]Wright, A.L., Hons, F.M. and Matocha, J.E. (2005). Tillage impacts on microbial biomass and soil organic carbon and nitrogen dynamics of corn and cotton rotations. Appl Soil Ecol 29, 85-92.

[51]Liu, Y.C., Zeng, X.Z., Feng, W.Q., Qin, Y.S., Wang, C.Q. and Tu, S.H. (2014). Effects of long-term straw mulch and fertilization on crop yields and soil physical and chemical properties under rice-rapeseed rotation. J Plant Nutr Fertil 20, 1450-1459.

[52]Basir, A., Jan, M.T., Alam, M., Shah, A.S., Afridi, K., Adnan, M., Ali, K., and Mian, I.A. (2016). Impacts of tillage, stubble management, and nitrogen on wheat production and soil properties. Can J Soil Sci 97, 133-140.

[53]Stewart, C., Roosendaal, D., Manter, D., Delgado, J. and Del Grosso, S. (2018). Interactions of stover and nitrogen management on soil microbial community and labile carbon under irrigated no-till corn. Soil Sci Soc Am J 82, 323-331.

[54]Urra, J., Mijangos, I., Lanzén, A., Lloveras, J. and Garbisu, C. (2018). Effects of corn stover management on soil quality. Eur J Soil Biol 88, 5764.

[55]Samara, E., Matsi, T., Barbayiannis, N. and Lithourgidis, A. (2020). Liquid cattle manure effect on corn yield and nutrients' uptake and soil fertility, in comparison to the common and recommended inorganic fertilization. J Soil Sci Pl Nutr 20, 22832293.

[56]Erinle, K. O. and Marschner, P. (2020). Wheat growth-induced changes in phosphorus pools in the crop residue detritusphere are influenced by residue C/P ratio. J Soil Sci Pl Nutr 20, 2579-2586.

[57]Abiven, S., Recous, S., Reyes, V., and Oliver, R. (2005). Mineralisation of $\mathrm{C}$ and $\mathrm{N}$ from root, stem and leaf residues in soil and role of their biochemical quality. Biol Fertil Soils 42, 119-128.

[58]Erinle, K.O., Li, J., Doolette, A. and Marschner, P. (2018). Soil phosphorus pools in the detritusphere of plant residues with different $\mathrm{C} / \mathrm{P}$ ratio - influence of drying and rewetting. Biol Fertil Soils 54, 841-852.

[59]Gao, C., El-Sawah, A. M., Ali, D. F. I., Hamoud, Y. A., Shaghaleh, H. and Sheteiwy, M. S. (2020). The integration of bio and organic fertilizers improve plant growth, grain yield, quality and metabolism of hybrid maize (Zea mays L.). Agronomy, 10, 319; doi: 10.3390/agronomy10030319

[60]Du, Z.J., Chen, X.M., Qi, X.B., Li, Z.Y., Nan, J.K. and Deng, J.Q. (2016). The effects of biochar and hoggery biogas slurry on fluvo-aquic soil physical and hydraulic properties: A field study of four consecutive wheat-maize rotations. J. Soils Sediments, 16, 2050-2058.

[61]Maqshoof, A., Zahir, A.Z., Jamil, M., Latif, F.N.M. and Akhtar, M.F. (2014). Integrated use of plant growth promoting rhizobacteria, biogas slurry and chemical nitrogen for sustainable production of maize under salt-affected conditions. Pak. J. Bot., 46, 375-382.

[62]Yadav, J., Verma, J.P., Rajak, V. K. and Tiwari, K.N. (2011). Selection of effective indigenous rhizobium strain for seed inoculation of chickpea (Cicer aritenium L.) production. Bacteriol J 1 (1), 24-30.

[63]Pii, Y., Mimmo, T., Tomasi, N., Terzano, R., Cesco, S. and Crecchio, C. (2015). Microbial interactions in the rhizosphere: beneficial influences of plant growth-promoting rhizobacteria on nutrient 
acquisition process. A review. Biol Fertil Soils 51, 403-415.

[64]White, P.J. and Broadley, M.R. (2009). Biofortification of crops with seven mineral elements often lacking in human diets - iron, zinc, copper, calcium, magnesium, selenium and iodine. New Phytol 182, 49-84.

[65]Abadi, V. A. J. M., Sepehri, M., Rahmani, H. A., Zarei, M., Ronaghi, A., Taghavi, S. M. and Shamshiripour, M. (2020). Role of dominant phyllosphere bacteria with plant growth-promoting characteristics on growth and nutrition of maize (Zea mays L.). J Soil Sci Pl Nutr 20, 2348-2363.

[66]Mwajita, M.R., Murage, H., Tani, A. and Kahangi, E.M. (2013). Evaluation of rhizosphere, rhizoplane and phyllosphere bacteria and fungi isolated from rice in Kenya for plant growth promoters. Springer Plus 2, 606.

[67]Batool, F., Rehman, Y., and Hasnain, S. (2016). Phylloplane associated plant bacteria of commercially superior wheat varieties exhibit superior plant growth promoting abilities. Front Life Sci 9, 313-322.

[68]Carrillo, A.E., Li, C.Y., and Bashan, Y. (2002). Increased acidification in the rhizosphere of cactus seedlings induced by Azospirillum brasilense. Naturwissenschaften 89, 428-432.

[69]Kudoyarova, G.R., Vysotskaya, L.B., Arkhipova, T.N., Kuzmina, L.U., Galimsyanova, N.F., Sidorova, L.V., Gabbasova, I.M., Melentiev, A.I. and Veselov, S.Y. (2017). Effect of auxin producing and phosphate solubilizing bacteria on mobility of soil phosphorus, growth rate, and $\mathrm{P}$ acquisition by wheat plants. Acta Physiol Plant 39, 253.

[70]Mustafa, S., Kabir, S., Shabbir, U. and Batool, R. (2019). Plant growth promoting rhizobacteria in sustainable agriculture: from theoretical to pragmatic approach. Symbiosis 78, 115-123.

[71]Hansen, V., Bonnichsen, L., Nunes, I., Sexlinger, K., Lopez, S. R., van der Bom, F.J.T., Nybroe, O., Nicolaisen, M. H. and Jensen, L. S. (2020). Seed inoculation with Penicillium bilaiae and Bacillus simplex affects the nutrient status of winter wheat. Biol Fertil Soils 56, 97-109.

[72]Barneix, A.J., Saubidet, M.I., Fatta, N., and Kade, M. (2005). Effect of rhizobacteria on growth and grain protein in wheat. Agron Sustain Dev 25, 505511.

[73]Chen, X.H., Koumoutsi, A., Scholz, R., Eisenreich, A., Schneider, K., Heinemeyer, I., Morgenstern, B., Voss, B., Hess, W.R., Reva, O., Junge, H., Voigt, B., Jungblut, P.R., Vater, J., Süssmuth, R.,
Liesegang, H., Strittmatter, A., Gottschalk, G., and Borriss, R. (2007). Comparative analysis of the complete genome sequence of the plant growthpromoting bacterium bacillus amyloliquefaciens FZB42. Mol Microb Ecol Rhizosph 2, 883-898.

[74]Allard-Massicotte, R., Tessier, L., Lécuyer, F., Lakshmanan, V., Lucier, J., Garneau, D., Caudwell, L., Vlamakis, H., Bais, H.P., and Beauregard, P.B. (2016). Bacillus subtilis early colonization of arabidopsis thaliana roots involves multiple chemotaxis receptors. Am Soc Microbiol 7, 1-10.

[75]Mendis, H.C., Thomas, V.P., Schwientek, P., Salamzade, R., Chien, J.T., Waidyarathne, P., Kloepper, J. and De La Fuente, L. (2018). Strain specific quantification of root colonization by plant growth promoting rhizobacteria Bacillus firmus I1582 and Bacillus amyloliquefaciens QST713 in non-sterile soil and field conditions. PLoS One 13:e0193119.

[76]López, J. E., Gallego, J. L., Vargas-Ruiz, A., PeñaMosquera, A. L., Zapata-Zapata, A. D., LópezSánchez, I. J. and Botero-Botero, L. R. (2020). Aspergillus tubingensis and Talaromyces islandicus solubilize rock phosphate under saline and fungicide stress and improve Zea mays growth and phosphorus nutrition. J Soil Sci Pl Nutr 20, 24902501.

[77]Sun, B., Gao, Y., Wu, X., Ma, H., Zheng, C., Wang, X., Zhang, H., Li, Z. and Yang, H. (2020). The relative contributions of $\mathrm{pH}$, organic anions, and phosphatase to rhizosphere soil phosphorus mobilization and crop phosphorus uptake in maize/alfalfa polyculture. Plant Soil 447, 117-133.

[78]George, T.S., Richardson, A.E. and Simpson, R.J. (2005). Behaviour of plant-derived extracellular phytase upon addition to soil. Soil Biol Biochem 37, 977-988.

[79]El Mazlouzi, M., Morel, C., Robert, Th., Yan, B. and Mollier, A. (2020). Phosphorus uptake and partitioning in two durum wheat cultivars with contrasting biomass allocation as affected by different $\mathrm{P}$ supply during grain filling. Plant Soil 449, 179-192.

[80]Ismail, M.M. and Moursy, A.A. (2018). Organo mineral fertilization of wheat: impact on growth and $\mathrm{N}$ - recovery using ${ }^{15} \mathrm{~N}$-stable isotope. Bangladesh J. Bot. 47 (4), 815-821.

[81]Soliman, M. A. E. (2018). Wheat response to Azospirillum inoculation, organic amendments and mineral nitrogen fertilizer with application of ${ }^{15} \mathrm{~N}$ stable isotope technique. J. Soil Sci. and Agric. Eng., Mansoura Univ., Vol. 9 (12), 821-827. Arab J. Nucl. Sci. Appl., Vol. 54, 4, (2021) 
[82]Ding, W., Li, S., He, P. and Huang, S. (2019). Contribution and fate of maize residue- ${ }^{15} \mathrm{~N}$ and urea- ${ }^{15} \mathrm{~N}$ as affected by $\mathrm{N}$ fertilization regime. PLoS ONE 14 (1), e0210176. https://doi.org/10.1371/ journal.pone.0210176

[83]Chen, Z., Wang, H., Liu, X., Lu, D. and Zhou, J. (2016a). The fates of ${ }^{15} \mathrm{~N}$-labeled fertilizer in a wheat-soil system as influenced by fertilization practice in a loamy soil. Scientific Reports | 6, 34754 | DOI: 10.1038/srep34754.

[84]Chen, Z., Wang, H., Liu, X., Liu, Y., Gao, S., and Zhou, J. (2016b). The effect of $\mathrm{N}$ fertilizer placement on the fate of urea- ${ }^{15} \mathrm{~N}$ and yield of winter wheat in southeast China. PLoS ONE 11(4), e0153701. doi:10.1371/journal.pone.0153701

[85]Piccoli, I., Sartori, F., Polese, R. and Berti, A. (2020). Crop yield after 5 decades of contrasting residue management. Nutr Cycl Agroecosyst 117, 231-241.

[86]Omara, P., Aula, L. and Raun, W. R. (2019). Nitrogen uptake efficiency and total soil nitrogen accumulation in long-term beef manure and inorganic fertilizer application. International Journal of Agronomy Volume 2019, Article ID 9594369, 6 pages doi.org/10.1155/2019/9594369 